\title{
Okulların Örgütsel DNA Özellikleri Ölçeğinin Geliştirilmesi Çalışması
}

\author{
DOI: 10.26466/opus.885896
}

\author{
Davut Nacar ${ }^{*}$ - Zülfü Demirtaş** \\ * Öğr.Gör., Kahramanmaraş Sütçü İmam Üniversitesi, SHMYO, Kahramanmaraş/Türkiye \\ E-Posta: davutncr2007@gmail.com \\ ORCID: 0000-0002-0137-4923 \\ ** Prof. Dr., Fırat Üniversitesi, Eğitim Fakültesi, Elazı̆̆/Türkiye \\ E- Posta: zdemirtas@firat.edu.tr \\ ORCID: 0000-0002-1072-5772
}

\section{Öz}

Tipkı canllarda olduğu gibi örgütlerin de yapllarnnn ne olduğu, hangi özeliklere sahip olduğu ve gelecekte ne gibi problemlerle karşılaşabileceklerinin tespit edilmesi daha verimli, sağllkl ve uzun ömürlü örgütlenmelerin gerçekleştirilmesine imkân verecektir. Buradan hareketle bu çalş̧mada okullarn örgütsel DNA özelliklerinin belirlenmesinde kullanilabilecek geçerli ve güvenilir bir veri toplama aracının geliştirilmesi amaçlanmaktadır. Çalışmaya, 2019-2020 Kahramanmaraş ili merkez On İki Şubat ve Dulkadiroğlu ilçelerinde Anadolu lisesi, ortaokul ve ilköğretim okulunda farklı branşlarda görev yapan 694 öğretmenin doldurmuş olduğu ölçek seti dâhil edilmiştir. Araştırmanın verileri SPPS for Windows 22 ve AMOS 16 programı kullamlarak çözümlenmiştir. Ölçeğin faktör yapısını ortaya çıkarmak için Açımlayıcı Faktör Analizi (AFA) yapılmıştır. Açımlayıcı faktör analizi sonucunda ölçek maddelerinin dört faktör ve 14 madde altında toplandığı görülmüştür. Oluşan bu faktörler literatüre baklarak iletişime açık, girişimci, bürokratik ve başıboş okul olarak etiketlenmiştir. Ölçeğin uygulandığı hedef kitle ve ölçeğin geçerlilik ve güvenirlik bulguları birlikte değerlendirildiğinde ilköğretim (ilkokul ve ortaokul) ve orta öğretim okullarmın örgütsel DNA özelliklerinin belirlenmesinde geçerli ve güvenilir bir araç olduğu söylenebilir. Ölçeğin yükseköğretim kurumlar içinde kullanılabilmesi için ölçekte bazı düzenlemeler yapılarak yeniden bir geçerlilik ve güvenirlik çalışmasının yapılması gerekebilir.

Anahtar Kelimeler: Örgütsel DNA, Organik ve Mekanik Örgüt, Ölçek Geliştirme. 


\title{
Development of a Scale for Organizational DNA Characteristics of Schools
}

\begin{abstract}
Just as in living things, determining the structures of organisations, what features they have and what problems they may encounter in the future will enable more efficient, healthy, and long-lasting organisations to be realised. Therefore, in this study, it is aimed to develop a valid and reliable data collection tool that can be used to determine the organisational DNA characteristics of schools. In the study, the scale set filled by 694 teachers working in different branches in Anatolian high school, middle school and primary schools in Kahramanmaraş's Onikişubat and Dulkadiroğlu districts in 2019-2020 academic year was included. The data of the research were analysed using SPSS 22 and AMOS 16. Exploratory Factor Analysis (EFA) was performed to reveal the factor structure of the scale. As a result of the exploratory factor analysis, it was observed that the scale items were collected under four factors and 14 items. These factors are labelled as open to communication, entrepreneurial, bureaucratic, and stray schools based on the literature. When the target audience and the validity and reliability findings of the scale are evaluated together, it can be said that it is a valid and reliable tool in determining the organisational DNA characteristics of primary and secondary schools. In order for the scale to be used in higher education institutions, it may be necessary to make a new validity and reliability study by making some adjustments on the scale.
\end{abstract}

Key Words: $\quad$ Organizational DNA, Organic and Mechanical Organization, Scale Development. 


\section{Giriş}

İçinde bulunduğumuz çağda örgütler, değişimin çok hızlı olduğu dinamik bir çevreyle karşı karşıyadır. Bu dinamik çevre ile beraber örgütler mekanik örgüt anlayışından sıyrılıp yavaş yavaş organik örgüt anlayışına geçmektedir (Sagnak, 2016). Her alanda olduğu gibi yönetim alanında da her geçen gün birçok yenilikler olmakta yeni yeni gelişmeler yaşanmakta ve literatüre yeni kavramlar eklenmektedir. Her yeni kavram, mevcut düşünceye yeni bir bakış açısı getirmekte ve yönetim sürecine farklı yaklaşılmasını sağlamaktadır. Kavramların düşüncelere giydirilmiş elbiseler olduğu düşünüldüğünde iyi bir kavram analizi, o kavramı kullananların düşüncelerini anlamaya yardımcı olacaktır.

Örgütler varlıklarını sağlık bir şekilde devam ettirebilmek amacıyla yeni gelişmeleri takip etmekte, yapı ve işleyiş̧lerini bu doğrultuda gözden geçirmektedirler. Diğer örgütlerde olduğu gibi eğitim örgütleri de kendi yapılarına uygun olarak bu yeni gelişmelere uyum sağlamaya çalışmaktadırlar. Örgütler önceleri makine gibi algılanırken artık bu anlayış organik bir yapıya bürümektedir. Mekanik bakış açısı örgütleri bir makine gibi görürken, bu anlayış değişikliği ile beraber örgütler organik bakış açısıyla canlı bir organizma gibi görülmektedir. Mekanik örgüt anlayışından organik örgüt anlayışına geçilirken örgütlerin yapı ve işleyişi canlı organizmalarla ilişkilendirilmektedir. Bu ilişkilendirmelerle birlikte literatüre son zamanlarda örgüt DNA'sı (Deoksiribo Nükleik Asit) kavramı eklenmiştir.

Örgütlerle ilgili birçok konu sürekli araştırılmakta ve güncellenmektedir. Yönetimde en çok araştırılan konular arasında yer alan örgütlerin etkililiği günümüzün en temel problemlerinden birisidir (Toytok ve Karpuzoğlu, 2015). Her örgütün kendi özelliklerini yansitan kendine özgü bir yapısı bulunmaktadır. Örgütlerin çalışma şekillerinin anlaşılmasında, örgütün yapısını oluşturan her bir bileşenin işleyiş biçimini bilmeye ihtiyaç vardır (Döş ve Çetin, 2014). Son yıllarda örgütleri yaşayan birer organizma olarak kabul ederek; her bir örgütün kendine has bir takım karakteristik özellikleri bulunduğu ve bu özelliklerin onu diğer örgütlerden ayırdığı düşünülmektedir. Canlılarda organizmanın kim ve ne olduğunu ifade eden kodlanmış bilgi DNA'dır (Akgül, 2003) ve düşünce organizasyonlarda örgüt DNA'sı kavramıyla açılanmaktadır. 
Yönetim alanına giren örgüt DNA'sı kavramını bilim adamları farklı şekillerde tanımlamışlardır. Govindarajan ve Trimble (2005) tarafından Örgüt DNA'sı bir örgüt içindeki yapı, kültür, işgören ve sistem döngüsü olarak tanımlanmaktadır. Adams ve Adams (1997) örgüt DNA'sını, canlıların DNA'sına benzetmekte ve örgütün DNA'sının örgütün kültürü olduğunu belirtmektedirler (Işık ve Gürsel, 2009). Tanımlamalarda örgüt kültürüne vurgu yapıldığı görülmektedir.

Bu tanımlamalarla birlikte örgüt DNA'sı kavramına bilim adamlarını bakış açıları da farklılaşmaktadır. Bir bakış açısına göre örgüt DNA'sı organik kimliğe uygun olarak örgütteki insanların, kendi kendine organize olacak şekilde çalışabilmek için ihtiyaç duyduğu yapı ve işlemlere ait bilgilerden oluşan bir veri tabanıdır. İkinci bir bakış açısı ise Örgütsel DNA'nın temel ilişkilerden oluştuğunu varsaymaktadır. Booz Allen şirketinin araştırmacılarının bakış açısına göre ise örgütsel DNA'yı belirleyen dört temel yapı (yapı, karar yetkisi, güdüleyiciler ve bilgi) bulunmaktadır (Verschoor, 2005). Tüm bu tanımlamalar ve bakış açılarıyla birlikte örgüt DNA'sı kavramının daha iyi anlaşılabilmesi için organik örgüt modeli kavramı ile birlikte açıklanmasında fayda vardır.

Örgütün bütün işlemleri ve yapısı kendi kimliğine göre dizildiğinde örgüt DNA'sına benzer bir olgu ortaya çıkmaktadır. İşgörenlerin, hayatlarını nitelikli bir şekilde sürdürebilmeleri ve çalıştıkları kurumda yüksek performans sergileyebilmeleri için, ihtiyaç duyduğu şeylerin tedarik edilmesi düşüncesi, örgüt kuramları üzerine çalışan araştırmacıların dikkatini biyolojiye yönlendirmiştir. Çünkü örgüt çalışanlarının hem birey hem de grup olarak biyolojik organizmalar şeklinde hareket ettikleri ve etkin şekilde faaliyette bulunmaları için ihtiyaçlarının karşılanmas1 gerektiği düşünülmektedir (Morgan, 1997). Bu yaklaşımla birlikte örgütlerin de birer organizma olduğu fikri, dikkatleri örgütsel etkinlik, örgüt - çevre ilişkileri ve varlığın sürdürülmesi gibi konulara çekmiştir.

Canlı organizmaları oluşturan küçük parçalar, belli kurallar içinde organize olarak bir araya gelirler ve ardından daha büyük parçaları oluştururlar. Maddenin en küçük yapıtaşı olan atomlar molekülleri, moleküller de farklı yapıları oluştururlar. Bu durum türlerde ve ekolojilerde bu şekilde devam eder. Büyük yapılar küçük parçalardan oluşur ve bunun tersi olmaz. Büyük yapıları meydana getiren bu küçük yapıların organi- 
ze olan parçalarının düzeni, biyolojide olduğu gibi ekonomilerde de geçerlidir (Meyer ve Davis 2003).

İnsanın DNA yapısından ilham alınarak, insanların genetik yapısını belirleyen ve insan bedeninde kalıtsal faaliyetlere sebep olan DNA, örgütlere uyarlanarak ve aynı insan DNA'sı gibi örgütlerin genetik yapıları tespit edilmeye çalışılmaktadır (Çetin \& Döş, 2014). Bu çalışmalarla birlikte her örgütün aynı insan organizmalarının sahip olduğu gibi DNA yapısına sahip olduğu düşüncesi gelişmeye başlamıştır.

Vücuttaki tüm hücreler aynı DNA'lara sahip olduğundan beyni oluşturan sinir hücreleri, vücuttaki herhangi bir hücre ile aynı DNA'lara sahiptir. Bir canlının sahip olduğu tüm bilgi birikimi hücre içindeki DNA'da kayıtlıdır ve bu, onun potansiyelini belirler. Diğer bir deyişle canlıların yönetsel molekülü DNA'dır (Beşoluk, Gündüz ve Önder, 2011). Bu bağlamda bir sosyal sistem içindeki örgütün yönetimi ile organizmanın bir hücresinin yönetimi bir metafor olarak ilişkilendirilebilir.

Başarılı işletme örneklerinden hareketle, örgütlerin günümüzün ekonomik koşullarına canlı bir organizma gibi uyum sağladıkları ve örgütlerin kendilerine özel genetik özelliklerinin olduğu, bu örgütlerin özelliklerinin de onların DNA'sında saklı olduğu Baskin (1998) tarafından ifade edilmektedir. Buradan hareketle bir organizmada bulunan bütün hücrelerin aynı DNA yapısına sahip olmaları gibi aynı sosyal sistem içinde bulunan örgütlerinde aynı özelliklerinin olduğu kabul edilebilir (Bancar, 2016; Beşoluk vd., 2011).

Literatür incelendiğinde farklı özelliklere sahip örgütlerin kendi özellikleri içinde açıklanmaya çalışıldığı görülmektedir. Ayı faaliyet kolunda çalışan örgütlerin bile kendine ait farklı özellikleri bulunmaktadır. Aşağıda bu farklı örgüt tipleri ve özellikleri açıklanmaktadır.

Pasif-Saldırgan (Passive-Agressive) Örgüt; Pasif-saldırgan örgüt hoş, herkesin birbiriyle anlaştığı, çatışmadan uzak ama içi kaynayan, güler yüzlü örgüt tipidir. Büyük değişimler için oy birliği sağlamak sorun değildir; öte yandan bu değişimleri uygulamak zordur. Yerleşik alan çalışmalarındaki direniş, rutin olarak şirket inisiyatiflerini alt eder. Anlamlı değişimler yaratmak için gerekli otorite, bilgi ve teşviklerin eksikliğinden, hat işgörenleri merkezden gelen emirlere aldırmamaya meyillidirler ve bunu "bu da geçer" diye yorumlamaktadırlar. Yine bu örgütlerde bilgi örtüktür ve en çok ihtiyaç duyanlar için ulaşılamaz bir haldedir. Bu 
kadar kötü özelliğinin sayılmasının yanı sıra, bu örgüt tipi, tanımlanan yedi örgüt tipi içerisinde en çok rastlananıdır. Geniş ve korunabilir bir pazar pozisyonuna sahip olan bu örgütler içten içe yavaş yavaş çökerlerken, bildikleri yolda devam etmektedirler (Neilson, Nuys ve Pasternak, 2005). Bunlar pasif-saldırgan örgütün en bilinen özellikleridir.

Esinlenmeler-Ve-Başlamalar (Fits-And-Starts) Örgütü; Fits-and-Starts tipi örgütlerde zeki, motive olmuş ve yetenekli insanların çalıştığı, ama genellikle aynı zamanda aynı yönde çalışmadıkları belirtilmektedir. Bunu başarabildiklerinde parlak, patlama yaratacak stratejik sonuçlara ulaşabildikleri; tipik olarak, gerçekte ise, bu başarılarını tutarlı bir temele oturtabilecek disiplin ve koordinasyondan yoksun oldukları gözlenmektedir. Fits-and-Starts örgüt, inisiyatif alabilen, girişimci eğilimleri olan, zeki insanları yanına çeker; bu tip örgütlerde bir fikir yakaladığınızda, limitsiz, kuralsız ve engelsiz bir ortam vardır. Ama tepede güçlü bir yönetimin olmadığı ve altında ortak değerlerin yerleştirilmediği bir yerde, bu inisiyatiflerin ya çarpışıp patladıkları veya yavaş yavaş tükendikleri gözlenmektedir. Sonucun kontrolden çıkma eşiğinde olduğu ve gereğinden fazla genişlemiş bir örgüt tipini yansıtmaktadır Karar yetkisi merkez dışında olmasına rağmen alınacak kararlar için gerekli bilgi merkezde bulunmaktadır (Çandır, 2005).

Fazla büyümüş (Outgrown) Örgüt; Örgüt, küçük bir tepe yönetim grubuyla yönetilemeyecek kadar çok geniş ve karmaşık bir hale gelmiştir ve yönetimini demokratikleştirmede daha çok yolu vardır. Bununla beraber, örgütün potansiyel birikiminin çoğu kullanılmamaktadır. Güç tepe ve tepeye yakın yerlerde tutulduğundan, fazla büyümüş örgüt pazardaki gelişmelere yavaş tepki vermeye meyillidir ve genellikle kendi yolunun dışına çıkamamaktadır. Böyle bir örgütün içerisinde bulunan bir kişi pozitif değişim fırsatlarını görebilir ama bunları eyleme geçirebilmesi ve sonuçlandırabilmesi oldukça zordur. Yukarıdan-aşağıya yönetim ve karar alma mirasının örgütün her yerine kökleşmiş olduğu ve eski alışkanlıkların kolay kolay silinmediği gözlenmektedir (Bancar, 2016; Çandir, 2005).

Yönetim Ağırlıklı (Overmanaged) Örgüt; Çok sayıda yönetim tabakaları bulunan, gereğinden fazla yönetim ağırlıklı örgütlerin "analiz felci" kavramı için bir durum çalışması niteliği gösterdiği belirtilmektedir. Harekete geçtiklerinde, yavaş ve tepkisel davrandıkları, fırsatları geç veya 
rakiplerine göre daha az enerjik takip ettikleri gözlenmektedir. Ormandan çok ağaçlarla uğraşan bu örgütlerin yöneticileri, zamanlarının çoğunu yeni fırsat ve tehditleri gözlemekten çok, astlarının işlerini kontrol etmekle geçirmektedir. Genellikle bürokratik ve yüksek seviyede politik davranan bu örgütün kendi kendini ateşleyen, proaktif ve sonuç-odaklı bireyleri engelledikleri gözlenmiştir (Çandır, 2005). Gereğinden fazla yönetim ağırlıklı örgütlerde, boşa harcanan çok fazla çaba ve gereksiz bilgi bulunmaktadır (Çandır, 2005). Çok fazla yönetim tabakasının olduğu bu örgütlerde terfiler gelenek haline geldiğinden vasatlığın liyakate hakim olduğu görülmektedir.

Tam-Zamanında (Just-in-Time) Örgüt; Her zaman değişim için proaktif olmasalar da bu tip örgütün gerektiğinde, büyük resmi kaybetmeden, pazardaki dalgalanmaların üstesinden geldiği belirtilmektedir. Just-inTime örgütler yetenekli ve motive insanların ilgi odağıdır. Bu tip örgüt ortamları genellikle eğlenceli, çılgın, öğrenmek için harika yerlerdir. Bu ortamların iş yerini motive eden maceracı bir tutumunun olduğu ve yaratıcı patlamalara ilham verdiği, özellikle de gerçek başarılara yol açtı̆̆ gözlenmektedir. Fakat tutarlılık ve disiplin eksikliğinde, örgüt bu fırsatlardan tam anlamıyla yararlanamadığ $\mathrm{Bu}$ gibi durumlarından dolayı genellikle, güvenilir bir rekabet avantajı sağlamaktan çok "bir atımlık baruta sahip" oldukları düşünülmektedir (Çandır, 2005). Eğitim örgütlerinin kendi içinde tutarlı ve disiplinli yapılarından dolayı, atama kriterleri belli olduğu için kabiliyetli ve motivasyonu yüksek insanları seçme ve çalıştırma olasılığı bulunmamaktadır. Eğitim örgütlerinde süreklilik esas olması gerektiğinden bu tip bir örgüt yapısı eğitim örgütleri için uygun gözükmemektedir.

Askeri (Military Precision) Örgüt; Genellikle küçük bir grup tepe yönetim ile yönetilen bu tip örgütlerin çok iyi çalıştıkları söylenebilir. Herkes kendi rolünü bilmekte ve dikkatlice uygulamaktadır ve bu da tutarlı ve akıcı uygulamaların toptan etkisini göstermektedir. Askeri örgüt sıkı bir hiyerarşi ve yüksek seviyede kontrollü bir yönetim modeliyle çalışır. Parlak stratejileri bünyesine alıp -genellikle tekrar tekrar- uygulayabilmektedir, çünkü örgüt talim etmiş ve el kitabındaki her senaryodan geçmiştir. Bu tip örgütün çok verimli çalıştığı ve hinterlandını, büyük boyuttaki işlerin altından ustalıkla kalkacak şekilde genişlettiği belirtilmektedir (Bancar, 2016; Çandır, 2005). 
Askeri örgütlerin, tipik olarak önemli ve beklenmedik bir değişim beklemedikleri için, ani değişimlere karşı zayıf oldukları belirtilmektedir (Çandır, 2005). Karar verme yetkileri eğitim örgütlerinde askeri örgütlerde olduğu gibi küçük bir grupta olmasına rağmen tepe yöneticiler liyakat esasına göre belirlenmemektedir. Tepe yöneticiler genellikle siyasetle geldiklerinden hükümet değişimleriyle tekrar değişmekteler. Bu sebepten dolayı tepe yönetime gelen kişiler genellikle eğitim yönetimiyle alakası olmayan kişilerden oluşmaktadır. Alanla ilgili bilgisi, tecrübesi ve yeteneği olmayan kişilerin tepe yönetimi işgal etmesi verimli ve etkili kararların alınamamasına sebep olmaktadır. Bu gibi sebeplerden dolayı eğitim örgütlerinin yapısı askeri tip örgüte de uymamaktadır.

Esnek (Resilient) Örgüt; Değişimlere kolay ve hızlı uyum sağlayabilecek kadar esnek olan bu tip örgütler, tutarlı bir işletme stratejisinin ardında sürekli odaklanmış ve düzenli kalabilmektedirler. İleriye dönük ve kendini yenileyen bu tip örgütün devamlı bir şekilde değişim beklentisi içinde olduğu ve bu değişimlere proaktif bir şekilde yaklaştıkları gözlenmektedir. Yolda bir engelle karşılaştı̆̆ında esnek örgüt bu engele gösterdiği hızlı, titiz ve yapıcı tepkisi ile diğerlerinden ayrılır. Esnek örgütün, motive olmuş takım oyuncularını bünyesine çekmekle beraber onlara, sadece motive edici iş ortamları değil aynı zamanda karmaşık problemleri çözebilmek için gerekli kaynak ve yetkiyi de sağladığı belirtilmektedir. Tüm örgüt yapıları içerisinde esnek örgüt tipinin en sağlıklı örgüt tipi olduğu belirtilmektedir. Örgüt, iyi bir çalışma sistemine sahip olabilir ama bu durum, kendinden memnun olma rahatlığına geçmesini gerektirmez. Onların her zaman bir sonraki rekabetçi savaş veya pazar yeniliği için ufku gözetledikleri belirtilmektedir (Bancar, 2016; Çandır, 2005).

Bütün örgütler yukarıda açıklanan herhangi bir örgüt kalıbına girebilir veya bunlardan bazılarına ait özellikleri kendisinde barındırabilir. Örgütlerin hangi tip örgüt yapısına sahip olduğu ile ilgili karar verilirken onların yapı, karar yetkisi, güdüleyiciler ve bilgi gibi daha birçok özelliğine bakılır. Örgütlerde bunların oluşması bazı yapılara bağlıdır. Mükemmel bir çalışma prensibine sahip olan canlıların vücutlarında bu işi gerçekleştiren yapı, hücrelerindeki DNA'lardır. Bir canlının yaşam süresi boyunca hangi işleri gerçekleştirebileceği ve gerçekleştiremeyeceği, nasıl bir karaktere sahip olacağı veya ne tür problemler yaşayacağı 
bilgisi onun hücrelerindeki DNA'larında mevcuttur. Tipk1 canlılarda olduğu gibi örgütlerin de yapılarının ne olduğu, hangi özeliklere sahip olduğu ve gelecekte ne gibi problemlerle karşılaşabileceklerinin tespit edilmesi daha verimli, sağlıklı ve uzun ömürlü örgütlenmelerin gerçekleştirilmesine imkân verecektir. Buradan hareketle bu çalışmada okulların örgütsel DNA özelliklerinin belirlenmesinde kullanılabilecek geçerli ve güvenilir bir veri toplama aracının geliştirilmesi amaçlanmaktadır.

\section{Araştırmanın Amacı}

Bu araştırmada. Okulların Örgütsel DNA Özelliklerinin belirlenmesi için geçerli ve güvenilir bir ölçeğin geliştirilmesi amaçlanmıştır.

\section{Yöntem}

Çalışmanın bu bölümünde ölçek geliştirme aşamalarına yer verilmiştir.

\section{Çalışma Grubu}

51 maddelik ölçek setinin geçerlik, güvenirlik ve açımlayıcı faktör analizi çalışmasının yürütülmesi için 2019-2020 Kahramanmaraş ili merkez Onikişubat ve Dulkadiroğlu ilçelerinde Anadolu lisesi, ortaokul ve ilköğretim okuluna 320 veri seti dağıtılmıştır. Dağıtılan ölçek setinden 24 ölçek seti hiç dönmediğinden 19 ölçek seti de yanlış ve hatalı doldurulduğu için araştırmanın birinci aşamasına dahil edilmemiş, böylece 277 veri seti üzerinden açımlayıcı faktör analizi yapılmıştır. Yapılan bu ilk uygulamanın ardından aynı evren içinde farklı bir gruptan, oluşturulan yapının doğruluğunu test etmek, doğrulayıcı faktör analizi ve güvenirlik analizleri yapmak için ikinci kez veri toplanmıştır. Çalışmanın bu ikinci aşaması için toplamda 460 ölçek seti okullara dağıtılmış, 20 ölçek seti hatalı doldurulması 23 ölçek setinin ise hiç dönüşü olmaması sebebiyle araştırmaya dahil edilmemiştir. Bundan dolayı çalışmaya 2019-2020 Kahramanmaraş ili merkez On İki Şubat ve Dulkadiroğlu ilçelerinde Anadolu lisesi, ortaokul ve ilköğretim okulunda farklı branşlarda görev yapan 417 öğretmenin doldurmuş olduğu ölçek seti dâhil edilmiştir. Açımlayacı ve 
doğrulayıcı faktör analizi için toplamda 694 öğretmenden veri toplanmiştır.

Ölçek geliştirme çalışmalarında, örneklem büyüklüğü ile ilgili literatürde farklı görüşler bulunmaktadır. Büyüköztürk (2002)'e göre, örneklemde yer alan kişilerin sayısının $\mathrm{n} / \mathrm{k} \geq 2$ minimum koşulunu sağlaması gerekmektedir. Geliştirilmeye çalışılan Okulların Örgütsel DNA Özellikleri Ölçeği (OÖDNAÖ) ölçeği 51 maddeden oluşmaktadır. Bu durumda $(296 / 51=5,80) \mathrm{n} / \mathrm{k} \geq 2$ minimum koşulunu sağlamaktadır.

\section{Madde Oluşturma}

OÖDNAÖ madde havuzunu oluşturmak için örgütsel DNA ile ilgili alanyazın taraması yapılmış ve başka araştırmacılar tarafından geliştirilen benzer ölçme araçları dikkatlice incelenmiştir. Bu çalışmayla geliştirilen OÖDNAÖÖ, Booz Allen şirketinin yayınladığı "Kurum DNA'sının Yedi Tipi" adlı çalışmaya dayanmaktadır. Booz Allen şirketinin yayınlamış olduğu kurum DNA'sının yedi tipinden yola çıkılarak okulların örgütsel DNA'sını belirlemeye yönelik 48 maddelik bir soru havuzu oluşturulmuştur. Oluşturulan soru havuzuyla ilgili olarak alanda uzman iki akademisyenin görüşleri alınmıştır. Ölçek maddelerindeki her bir sorunun tek bir özelliği ölçmesi gerektiği ilkesine dayanılarak, uzman akademisyen görüşleri doğrultusunda, bazı ölçek maddeleri ikiye bölünmüştür. Böylece soru havuzundaki madde sayısı 51'e çıkmıştır. Yine bazı sorular da uzmanların görüşleri doğrultusunda değiştirilmiştir. Örneğin "Okulda öğretmenlerin potansiyelleri tam anlamıla kullanılmamaktadır." ifadesi, "Okul öğretmenlerin potansiyellerinden tam olarak yararlanmamaktadır." şeklinde değiştirilmiştir.

Uzmanların görüşü alındıktan sonra oluşturulan 51 maddelik soru havuzu iki Türk Dili ve Edebiyatı uzmanına gönderilerek noktalama ve yazım yanlışı hataları düzeltilmiştir. Noktalama ve imla hatalarının düzeltilmesinden sonra dört farklı branşta öğretmenle ölçek maddeleri ile ilgili odak grup görüşmesi yapılmıştır. Görüşmede her öğretmene ölçek seti dağıtılmış ve ilk sorudan başlanarak öğretmenlerden soruları okumaları istenmiştir. İlk soru okunduktan sonra öğretmenlerin hepsine okuduğu sorudan ne anladığı sorulmuştur. Ölçülmek istenen durumla öğretmenlerin algıladığı durum arasında bir anlam farklılığının olduğu 
durumlarda anlam karışıklığını gidermek için gerekli düzeltmeler yapılmıştır. Örneğin "Okulda gereksiz çok fazla bilgi bulunmaktadır." ifadesi öğretmenler tarafından tam olarak anlaşılmadığı için "Okulda gereksiz çok fazla prosedür vardır." şeklinde düzeltilmiştir. Her bir ölçek maddesi bu şekilde gözden geçirilerek 51 soruluk ölçek setine son şekli verilmiştir.

\section{Verilerin Analizi}

Araştırmanın verileri SPPS for Windows 22 ve AMOS 16 programı kullanılarak çözümlenmiştir. Madde havuzunun katılım düzeyi için 5'li Likert tipi dereceleme seçilmiş ve dereceleme "her zaman (5), çoğunlukla (4), bazen (3), çok nadir (2) ve hiçbir zaman (1)" şeklinde belirlenmiştir. Tablo 1'de araştırma bulgularının karşılaştıılacağı uyum indeksleri yer almaktadır.

Tablo 1. Yapısal Eşitlik Modelinin Uyumuna İlişkin Değerler (Kline, 1998, s. 239; Schermelleh Engel and Moosbrugger, 2003, s. 52; Schumaker ve Lomax, 2004, s. 82; Tabachnick and Fidell, 2013, s. 703).

\begin{tabular}{lll} 
Ölçüm & İyi Uyum & Kabul Edilebilir Uyum \\
\hline $\begin{array}{l}\text { Genel Model Uyumu } \\
x^{2} \text { uyum testi }\end{array}$ & $\leq 3$ & $\leq 4-5$ \\
\hline Karşılaştırmalı Uyum İndeksleri & & \\
NFI & $\geq .95$ & $.90-.94$ \\
NNFI & $\geq .95$ & $.90-.94$ \\
IFI & $\geq .95$ & $.90-.94$ \\
CFI & $\geq .97$ & $\geq .95$ \\
RMSEA & $\leq .05$ & $.06-.08$ \\
\hline Mutlak Uyum İndeksleri & & \\
GFI & $\geq .90$ & $.89-.85$ \\
AGFI & $\geq .90$ & $.89-.85$ \\
\hline Koruyucu Uyum İndeksleri & \\
PNFI & $\geq .95$ & - \\
PGFI & $\geq .95$ & - \\
Artık Temelli Uyum İndeksi & & \\
RMR(SRMR) & & \\
& &
\end{tabular}




\section{Bulgular}

\section{Açımlayıcı Faktör Yapısına İlişkin Bulgular}

51 madden oluşan ölçek seti, ilk çalışma grubuna (277 kişilik) uygulandıktan sonra veri setinin faktör analizine uygun olup olmadığına bakmak için KMO katsayısı hesaplanmış ve Barlett Sphericity Testi yapılmıştır. Ölçeğin KMO değeri .867 olarak bulunmuştur. Barlett Sphericity Testi değerleri ise (1170.8: $\mathrm{p}=.000$ ) olarak bulunmuştur. Literatürde Kaiser-Meyer-Olkin of Measure of Sampling Adequacy değerinin .6'dan büyük olması ve Bartlett's Test Of Sphericity değerinin ise .05 ya da daha küçük olması beklenmektedir (Pallant, 2016). Bulunan bu değerler veri setinin faktör analizi yapmaya uygun olduğunu göstermektedir.

Ölçeğin faktör yapısını ortaya çıkarmak için Açımlayıcı Faktör Analizi (AFA) yapılmıştır. AFA, çok sayıda değişkeni belirli sayıda gruplara ayırarak her bir grupta yer alan değişkenler arasındaki ilişkiyi maksimum, gruplar arasındaki ilişkiyi ise minimum yaparak grupları yeni değişkenlere dönüştüren bir analiz yöntemidir (Karagöz, 2016).

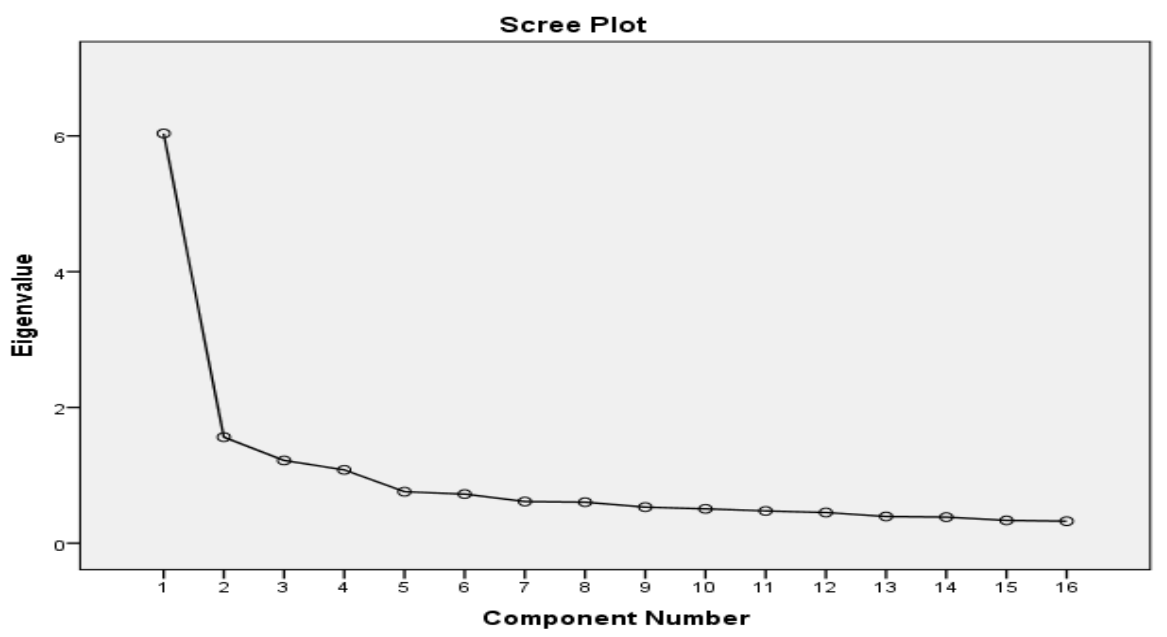

Şekil 1. OÖDNAÖ Faktörleri Özdeğerlerine Ait Saçılma Diyagramı.

Şekil 1 incelendiğinde AFA ilk analiz sonucunda ölçeğin öz değeri 1 'den büyük on iki faktör altında toplandığı görülmüştür. Dört faktörün 
öz değeri ve açıkladığı varyans oranı diğer faktörlerden yüksek olduğu şekil 1'de görülmektedir. Birinci faktörün kırılma noktasının diğer faktörlere göre biraz daha yüksektir. AFA sonucunda oluşan bu faktör yapısına ilişkin öz değerler ve açıklama varyansları Tablo 2'de verilmiştir.

Tablo 2. Faktör Öz Değerleri ve Açıklama Varyansları

\begin{tabular}{lllllll}
\hline \multicolumn{3}{l}{ Faktör } & \multicolumn{3}{l}{ Toşlangıç Öz Değer } & \multicolumn{5}{l}{ Döndürme Sonrası Toplam } \\
Vary \% & Küm \% & Toplam & Vary \% & Küm \% \\
\hline 1 & 4.929 & 35.208 & 35.208 & 2.771 & 19.793 & 19.793 \\
2 & 1.358 & 9.698 & 44.906 & 2.066 & 14.754 & 34.547 \\
3 & 1.231 & 8.790 & 53.696 & 1.963 & 14.021 & 48.568 \\
4 & 1.123 & 8.018 & 61.714 & 1.840 & 13.146 & 61.714 \\
\hline
\end{tabular}

Kaiser kriterine göre 1 ya da daha yüksek öz değere sahip olan faktörlerle ilgileniriz (Pallant, 2016). Tablo 2'ye bakıldığında öz değeri 1'den büyük dört faktör olduğu görülmektedir. Bu dört faktör toplam varyansın 61.714'ünü açılamaktadır. Faktörlerin başlangıç ve döndürme sonrası açıkladıkları varyans oranı karşılaştırıldı̆̆ında birinci faktörün varyansının 35.64'ten 19.79'a düştüğünü, ikinci faktörün varyansının $9.70^{\prime}$ den $14.75^{\prime}$ e, üçüncü faktörün varyansının 8.79 'dan 14.02 'ye ve dördüncü faktörün varyansının 8.01 'den $13.15^{\prime}$ e çıktığını görüyoruz.

Literatüre bakıldığında bir maddenin bir faktörde yer alabilmesi için o faktöre .40 değerinde yük vermesi gerektiği ifade edilmektedir (DeVellis, 2003; Field, 2005). Birden fazla faktöre yük veren maddeler de yük verdiği faktörler arasında .100 'den daha küçük yük değeri farkına sahip olduğu için ölçekten çıkarılmıştır. Bu işlem yapılırken farkın en az oldu$\breve{g}$ u maddeler tek tek çıkarılarak işlem tekrar etmiştir. Bu durumda olan $24,16,44,38,33,40,7,11,18,51,42,46,50,45,23,36,51,4,20,26,27,28$, $30,32,34,1,16,13,12,7,21,8$ ve 35 . maddeler ölçekten çıkarılmıştır. Hiçbir faktöre yük değeri vermeyen 15, 25 ve 37. maddeler ve yine tek maddelik faktör oluşturan 2, 31 ve 6 . maddeler de ölçekten çıkarılmıştır. Ölçekten çıkarılan 18. (Okul, öğretmenlerin kariyer gelişimini engeller.) ve 50. (Okulda öğretmenler, disiplinsiz davranışlar sergiler.) maddeler araştırmacı tarafından ölçekte olması gerektiği düşünülerek tekrar ölçeğe dâhil edilip veri setine yeniden AFA yapılmış 14 maddelik 4 faktörlü yapı oluşmuştur. Ölçek maddelerine ait faktör yük ve güvenirlik değerleri Tablo 3'te gösterilmektedir. 
Tablo 3. OÖDNAÖ Faktör Yük ve Güvenirlik Değerleri

\begin{tabular}{|c|c|c|c|c|c|c|}
\hline & Faktör 1 & Faktör 2 & Faktör 3 & Faktör 4 & $\begin{array}{l}\text { Güvenirlik } \\
\text { Faktörler }\end{array}$ & $\begin{array}{l}\text { Güvenirlik } \\
\text { Toplam }\end{array}$ \\
\hline i1 & .799 & & & & & \\
\hline i2 & .748 & & & & & \\
\hline i3 & .699 & & & & .812 & \\
\hline i4 & .636 & & & & & \\
\hline i5 & .634 & & & & & \\
\hline İ6 & & .798 & & & & \\
\hline İ7 & & .708 & & & .660 & .853 \\
\hline İ8 & & .686 & & & & \\
\hline İ9 & & & .797 & & & \\
\hline i10 & & & .794 & & .756 & \\
\hline i11 & & & .730 & & & \\
\hline i12 & & & & .730 & & \\
\hline i13 & & & & .731 & 639 & \\
\hline i14 & & & & .668 & & \\
\hline
\end{tabular}

Tablo 3'e bakıldığında OÖDNAÖ ölçeğinin 4 faktörden oluştuğu görülmektedir. Birinci faktörde beş, ikinci, üçüncü ve dördüncü faktörlerde üçer madde olmak üzere ölçek toplam 14 maddeden oluşmaktadır.

\section{Doğrulayıcı Faktör Yapısına İlişkin Bulgular}

Tanımlanan yapının doğrulanıp doğrulanmadığını kontrol etmek için ölçek farklı bir öğretmen grubuna tekrar uygulanmıştır. AFA analizi sonucu oluşun 14 madde ve 4 faktörlü ölçeğin yapı geçerliliğinin doğruluğunun belirlenmesi için Doğrulayıcı Faktör Analizi (DFA) yapılmıştır. Oluşturulmuş olan faktörler (gizil değişkenlerin) arasındaki ilişkiyi de modele dahil eden birincil seviye DFA yapılmıştır (Meydan ve Şeşen, 2015). AFA, hangi değişken gruplarının hangi faktör ile yüksek düzeyde ilişkili olduğunu test etmek amacıyla kullanılırken belirlenen belli sayıda faktöre katkıda bulunan değişken gruplarının bu faktörler ile yeterli düzeyde temsil edilip edilmediğinin belirlenmesi için DFA'dan faydalanılır (Aytaç ve Öngen, 2010). Yani DFA önceden belirlenmiş bir yapının doğruluğunu belirlemeyi amaçlar. DFA analizi sonucu, ölçeğin maddeleri ve faktör yapıları, ölçeği geliştiren araştırmacılar ve alanda iki uzman tarafından ölçeğin kapsamının ve faktör içi tutarlılığının incelenmesiyle ölçeğe son şekli verilmiştir. 


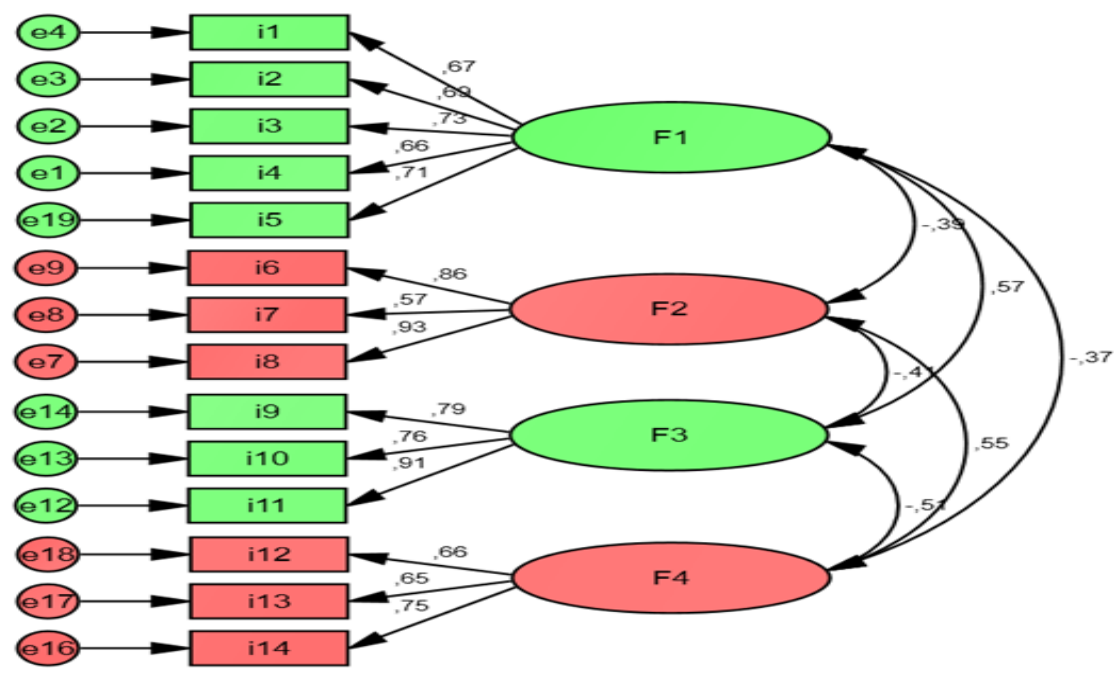

Şekil 2. Standartlaştırılmış Regresyon Ağırlıkları Diyagramı

Şekil 2'ye bakıldığında gizil değişken olan F1, F2, F3, ve F4'ten gözlenen değişkenlere doğru çizilen tek yönlü oklar, tek yönlü doğrusal ilişkiyi göstermektedir. Bu değişkenler kendi gizil değişkeninin ne kadar iyi temsilcisi olduğuna ilişkin bilgi verir. Örneğin, diyagramda standardize edilmiş verilere bakıldığında F1 gizil değişkenini en iyi temsil eden gözlenen değişken, .73'lük yüküyle i3'tür. F1 gizil değişkenini en az etkileyen gözlenen değişken ise .66'lık yük değeriyle i4'tür. Faktörler arasında pozitif yönlü en yüksek ilişki F1 ile F3 arasındadır. Diğer uyum indekslerine ilişkin dağılım Tablo 4'te yer almaktadır.

Tablo 4. OÖDNAÖÖ'nün Uyum İndeksi Değerleri

\begin{tabular}{llllllll}
\hline Uyum İndeksi Değerleri & $\boldsymbol{x}^{2 /(\boldsymbol{d} f)}$ & SRMR & RMR & CFI & NFI & AGFI & GFI \\
& 1.814 & .045 & .042 & .98 & .95 & .94 & .96 \\
\hline
\end{tabular}

DFA'da modelin raporlanmasında hangi uyum indekslerinin kullanılacağ macının amacına bırakılmıştır. Yine de her çalışmada ki-kare ve SD ve iyilik uyum indeksleri mutlaka verilmekte; araştırmanın amacına uygun olarak da diğer indekslerden bazıları ifade edilmektedir (Meydan ve Şeşen, 2015). 
Tablo 4'te OÖDNAÖÖ'ne ilişkin uyum indeksi değerleri incelendiğinde ki-kare ( $\left.\mathrm{x}^{2} / \mathrm{df}=1.814\right)$, SRMR (.045), RMR (.042), CFI (.98), NFI (.95), AGFI (.94) ve GFI (.96) değerlerine ait bulgular, yapısal eşitlik modelinin uyumuna ilişkin değerler tablosu ile karşılaştırıldığına tüm değerlerim kabul edilebilir ve iyi uyum sergiledikleri görülmektedir.

\section{Güvenirliğe İlişkin Bulgular}

OÖDNAÖ ölçeğinin açımlayıcı faktör analizinden sonra ölçeğin tamamı ve faktörlerine yönelik güvenirlik katsayıları Tablo 5'te görülmektedir.

Tablo 5. OÖDNAÖ Ölçeğine ait Cronbach Alpha Güvenirlik Sonuçlarn

\begin{tabular}{llllll}
\hline Faktörler & $\mathbf{1}$ & $\mathbf{2}$ & $\mathbf{3}$ & $\mathbf{4}$ & Ölçek Toplamı \\
Madde Sayısı & 5 & 3 & 3 & 3 & 14 \\
Cronbahc Alpha & .819 & .809 & .856 & .728 & .880 \\
\hline
\end{tabular}

Tablo 5'e baktığımızda Cronbach Alpha iç tutarlılık katsayısının, beş maddeden oluşun birinci faktörünün .819 , üç maddeden oluşan ikinci faktörün .809 , üç maddeden oluşan üçüncü faktörün .856, yine üç maddeden oluşan dördüncü faktörün .728 ve ölçek genelinin .880 olduğu görülmektedir. Cronbach Alpha iç tutarlılık katsayısının sosyal bilimlerde .6'nin üzerinde olması kabul edilebilir bir değerdir. Ölçek geneline ve faktör bazında tüm değerlerin kabul edilebilir değer olan .6'nın üzerinde olduğu görülmektedir.

\section{Tartışma ve Sonuç}

Bu çalışmada okulların örgütsel DNA özelliklerinin belirlenmesinde kullanılabilecek geçerli ve güvenilir bir veri toplama aracının geliştirilmesi amaçlanmıştır. Başlangıçta 48 maddeden oluşan Okulların Örgütsel DNA Özellikleri Ölçeği (OÖDNAÖÖ) ön uygulama ve uzman görüşleri sonucunda bazı düzenlemeler yapılarak 51 madde olarak hazırlanmıştır. 51 maddeden oluşan ölçek formu örneklem grubuna uygulanmış ve elde edilen veriler üzerinde analizler yapılmıştır. Yapılan AFA sonucunda ölçek maddelerinin dört faktör altında toplandığ1 görülmüştür. Bu faktörler "İletişime Açık Okul", "Başıboş Okul", "Girişimci Okul" ve "Bürokratik Okul" olarak adlandırılmıştır. Hiyerarşinin çok sıkı olduğu as- 
kerî örgütün özelliklerine ait bir faktörün oluşmaması, okulların böyle bir yapıya uygun olmadığından kaynaklanıyor olabilir. 37 madde; birden fazla faktörde yüksek yük değerine sahip olmaları, bulundukları faktördeki diğer maddelerle uyumlu olmamaları, tek maddelik faktör oluşturmaları nedeniyle ölçekten çıkartılmıştır.

OÖDNAÖÖ'nin tamamı için Cronbach Alpha iç tutarlılık katsayısı .880 olarak bulunmuştur. Elde edilen sonuçlara göre ölçek yüksek derecede iç tutarlığa sahiptir. Ölçeğin AFA sonucu elde edilen dört faktör altında toplanan 14 maddelik yapısına, doğrulayıcı faktör analizi yapılmıştır. DFA ile hesaplanan uyum iyiliği değerleri şöyledir: $\left(\mathrm{x}^{2} / \mathrm{df}=1.814\right)$, SRMR (.045), RMR (.042), CFI (.98), NFI (.95), AGFI (.94) ve GFI (.96). Elde edilen uyum indekslerinin tümünün model uyumu için yeterli düzeyde olduğu belirlenmiştir. Elde edilen bulgulara bakarak ve uzman görüşleri alınarak yapının doğru olduğuna karar verilmiştir.

OÖDNAÖÖ'nin nihai formu 14 maddeden oluşmakta ve tüm maddeler; "1-hiçbir zaman, "2-çok nadir", "3-bazen", "4-çoğunlukla" ve "5-her zaman" şeklinde puanlanmaktadır. Ölçeğin tümünden elde edilen toplam puana göre bir yorumlama yapılamamaktadır. Her bir faktörde farklı sayıda madde bulunduğundan her bir boyuttan alınan puanın, ilgili boyutun madde sayısına bölünmesi ve 1 ile 5 arası bir ortalamaya dönüştürülerek birbiri ile karşılaştırılabilir hâle getirilmesi gerekir. Herhangi bir faktörden alınan puanın büyük olması okulun o faktöre ait olan özellikleri daha fazla yansıttığını gösterir. Başıboş (6, 7 ve 8 . madde) ve bürokratik okul (12, 13 ve 14 . madde) faktörlerine ait maddeler ölçeğin tamamı için güvenirlik değerlerine bakılırken ters çevrilmelidir.

Ölçeğin uygulandığı hedef kitle ve ölçeğin geçerlilik ve güvenirlik bulguları birlikte değerlendirildiğinde ilköğretim (ilkokul ve ortaokul) ve orta öğretim okullarının örgütsel DNA özelliklerinin belirlenmesinde geçerli ve güvenilir bir araç olduğu söylenebilir. Ölçeğin yükseköğretim kurumlarında kullanılabilmesi için ölçekte bazı düzenlemeler yapılarak yeniden bir geçerlilik ve güvenirlik çalışmasının yapılması gerekebilir. Ulaşılan bulgular doğrultusunda bu çalışmayla geliştirilen aracın ilgili alanyazındaki önemli bir eksikliği gidereceği, bundan sonraki çalışmalarda kullanılabilecek nitelikte ve yeterlilikte bir ölçme aracı olma özelliği taşıdığı söylenebilir. 


\title{
EXTENDED ABSTRACT
}

\section{Development of a Scale for Organizational DNA Characteristics of Schools}

\author{
Davut Nacar - Zülfü Demirtaş \\ Sütçü Imam Univesity- Fırat Univesity
}

In the age we live in, organizations are faced with a dynamic environment where change is very rapid. With this dynamic environment, organizations are getting rid of the mechanical organization understanding and gradually moving to the organic organization understanding. As in every field, there are many innovations and new developments in the field of management every day, and new concepts are added to the literature. Each new concept brings a new perspective to existing thinking and provides a different approach to the management process. Considering that concepts are clothes for thoughts, a good concept analysis will help to understand the thoughts of those who use that concept.

While organizations were perceived as machines before, this understanding now takes on an organic structure. While the mechanistic perspective sees organizations as a machine, with this change in understanding, organizations are seen as living organisms with an organic perspective. The structure and functioning of organizations are associated with living organisms while transitioning from the understanding of the mechanical organization to the understanding of the organic organization. Along with these associations, the concept of organizational DNA (Deoxyribo Nucleic Acid) has been added to the literature recently. Scientists have defined the concept of organizational DNA, which is in the field of management, in different ways. Organizational DNA is defined by Govindarajan and Trimble as the structure, culture, employee, and system cycle within an organization. Adams and Adams liken the DNA of the organization to the DNA of living things and state that the DNA of the organization is the culture of the organization. It is seen that the definitions emphasize the organizational culture.

Inspired by the human DNA structure, DNA, which determines the genetic structure of people and causes hereditary activities in the human 
body, is adapted to organizations and the genetic structures of organizations, just like human DNA, are tried to be determined. With these studies, the idea that every organization has the same DNA structure as human organisms has started to develop.

While deciding what type of organizational structure an organization has, many more features such as structure, decision authority, motivations, and knowledge are taken into account. The formation of these in organizations depends on some structures. The structure that performs this job in the bodies of living things, which have a perfect working principle, is the DNA in their cells. The information that a living thing can and cannot perform during its lifetime, what kind of character it will have or what kind of problems it will experience is in the DNA of its cells. Just like living things, determining what the structures of organizations are, what features they have and what kind of problems they may encounter in the future will enable more efficient, healthy, and longlasting organizations to be realized. From this point of view, this study aimed to develop a valid and reliable data collection tool that can be used to determine the organizational DNA characteristics of schools.

In order to carry out the validity, reliability, and explanatory and confirmatory factor analysis study of the 51-item scale set, data were collected from a total of 694 teachers working in Anatolian high schools, middle schools, and primary schools in Onikişubat and Dulkadiroğlu provinces of Kahramanmaraş in 2019-2020 educational year. In order to create the item pool for the scale of organizational DNA characteristics of schools, a literature review on organizational DNA was conducted and similar measurement tools developed by other researchers were carefully examined. The Organizational DNA Characteristics Scale of Schools developed with this study is based on the study titled "Seven Types of Organizational DNA" published by Booz Allen company.

The data of the research were analyzed using SPPS for Windows 22 and AMOS 16 programs. A 5-point Likert-type rating was chosen for the participation level of the item pool, and the grading was determined as "always (5), often (4), sometimes (3), very rarely (2), and never (1)". As a result of the exploratory factor analysis, it was seen that there were four factors with an eigenvalue greater than 1 . These four factors explain 61,714 of the total variance. After the problematic items were removed 
from the scale set, a 14-item 4-factor structure was formed. The scale consists of 14 items in total, with five items in the first factor and three items each in the second, third and fourth factors. The scale was reapplied to a different group of teachers to check whether the defined structure was confirmed. Confirmatory Factor Analysis (CFA) was performed to determine the construct validity of the 14-item and 4-factor scale, which was formed as a result of exploratory factor analysis. When the fit index values of the Organizational DNA characteristics of the schools are examined, findings of chi-square $\left(\mathrm{x}^{2} / \mathrm{df}=1.814\right)$, SRMR (.045), RMR (.042), CFI (.98), NFI (.95), AGFI (.94) ve GFI (.96) values, the values for the fit of the structural equation model are acceptable and show good fit. These data show that the structure of the scale was confirmed.

After confirmatory factor analysis, it was seen that the Cronbach Alpha internal consistency coefficient of the scale was .819 for the first factor consisting of five items, .809 for the second factor consisting of three items, .856 for the third factor consisting of three items, .728 for the fourth factor consisting of three items, and .880 for the overall scale.

As a result of the EFA, it was seen that the scale items were gathered under four factors. These factors were named "Open Communication School", "Stray School", "Entrepreneurial School" and "Bureaucratic School". No interpretation can be made according to the total score obtained from the entire scale. Since each factor has a different number of items, the score obtained from each dimension should be divided by the number of items in the relevant dimension and converted to an average between 1 and 5 to make them comparable with each other. A higher score for any factor indicates that the school reflects the characteristics of that factor more. When the target group to which the scale is applied and the validity and reliability findings of the scale are evaluated together, it can be said that it is a valid and reliable tool in determining the organizational DNA characteristics of primary and middle schools.

\section{Kaynakça/References}

Akgül, A. (2003). Kamu yönetim sisteminin DNA'sını değiştirme modeli: 'Değģisim Mühendislĭgi' (2. Baskı). Ankara: Türkiye İsrafı Önleme Vakfı Yayınları. 
Aytaç, M. ve Öngen B. (2010). Doğrulayıcı faktör analizi ile yeni çevresel paradigma ölçeğinin yapı geçerliliğinin incelenmesi. İstatistikçiler Dergisi, 5(2012), 14-22.

Bancar, A. 2016. Örgüt DNA'sl. Ankara: Nobel Akademik Yayıncilık.

Baskin, K. (1998). Corporate DNA: Learning from life. USA: ButterworthHeinemann.

Beşoluk, Ş., Gündüz, H.B. ve Önder, İ. (2011). Karmaşık sistemlerde liderlik bakışıyla: DNA Liderlik. Uluslararası Insan Bilimleri Dergisi, 8(1), 521-544.

Büyüköztürk, Ş. (2002). Faktör analizi: Temel kavramlar ve ölçek geliştirmede kullanımı. Kuram ve Uygulamada Ĕ̈itim Yönetimi, 8(32), 470-483.

Çandır, E. (2005). Örgütsel DNA ve bir uygulama. (Yayınlanmamış Yüksek Lisans Tezi). Uludağ Üniversitesi, Sosyal Bilimler Enstitüsü, Bursa.

Döş, İ. ve Çetin, R. B. (2014). Örgüt DNA'sı Ölçeğinin geliştirilmesi ve MEB üzerine bir tarama çalışması. Uluslararası Sosyal Araştırmalar Dergisi, $7(31), 560-575$.

DeVellis, R. (2003). Scale development: Theory and applications. Thousand Oaks, CA: Sage.

Field, A. (2005). Discovering statistics using SPSS (2nd Ed.). London: Sage.

Govindarajan, V. and Trimble, C. (2005). Organizational DNA for strategic innovation. California Management Review, 47(3), 47-76.

Işık, A. N. ve Gürsel, M. (2009). Örgüt kültürünün bazı değişkenlere göre analizi. Selçuk üniversitesi Ahmet Keleşoğlu Ĕ̆itim Fakültesi Dergisi, 27, 187 -205.

Karagöz, Y. (2016). SPSS ve AMOS 23 uygulamaları. Ankara: Nobel Akademik Yayıncilik.

Kline R. B. (1998). Principles and practice of structural equation modeling. New York: Guildford Press.

Meydan, C.H. ve Şeşen, H. (2015). Yapısal eşitlik modellemeleri AMOS uygulamalarl. Ankara: Detay Yayıncilık.

Meyer, C. ve Davis, S. (2003). It's alive: The coming convergence of information, biology and business. New York: Crown Business.

Morgan, G. (1997). Yönetim ve örgüt teorilerinde metafor. (Çev. G. Bulut). İstanbul: MESS Yayınları, Yayın No: 280 (1997).

Neilson, G. L., Pasternak, A.B. and Nuys, K.E.V. (2005). The passive aggressive organization. USA: Harvard Business Review.

Pallant, J. (2006). SPSS kullanım klavuzu (Çev. S. Balcı ve B. Ahi). Ankara: Anı. 
Sagnak, M. (2016). Participative leadership and change-oriented organizational citizenship: The mediating effect of intrinsic motivation. Eurasian Journal of Educational Research, 62, 181-194.

Schermelleh Engel, K. and Moosbrugger, H. (2003). Evaluating the fit of structural equation models: Tests of significance and descriptive goodness-offit Measures. Methods of Psychological Research Online, 8(2), 23-74.

Schumacker, R. E. ve Lomax, R. G. (2004). A Beginner's guide to structural equation modeling (2nd ed.). Mahwah, New Jersey, US: Lawrence Erlbaum Associates Publishers.

Verschoor, C. C. (2005). Organizational DNA Should contain ethics component. Strategic Finance, 86(8), 19-20.

Tabachnick, B. G. and Fidell, L. S. (2013). Using multivariate statistics (6. Edition). Boston: Pearson Education.

Toytok, E. H. ve Kapusuzoglu, S. (2015). Influence of school managers' ethical leadership behaviors on organizational culture: Teachers' perceptions. Eurasian Journal of Educational Research, 66, 373-388.

\section{Kaynakça Bilgisi/Citation Information}

Nacar, D. ve Demirtaş, Z. (2021). Okulların Örgütsel DNA Özellikleri Ölçeğinin geliştirilmesi çalışması. OPUS- Uluslararası Toplum Araştırmaları Dergisi, 18(44), 7594-7615. DOI:10.26466//opus.885896. 